\title{
The Economy of Obligation: The Culture of Credit and Social Relations in Early Modern England
}

Review Number: 2043

Publish date: Thursday, 5 January, 2017

Author: Craig Muldrew

ISBN: 9780312215651

Date of Publication: 1998

Price: $£ 106.56$

Pages: 453pp.

Publisher: Palgrave Macmillan

Publisher url: http://www.palgrave.com/gb/book/9780312215651

Place of Publication: London

Reviewer: Jonathan Healey

Starting in around 1530, Craig Muldrew argues in this important, phenomenally good book, the English economy developed rapidly. Population growth fed commercialization; markets developed and embedded; people did not just grow and make things, they bought and sold, bargained and trucked. Yet there were few actual coins. Money was scarce, and as the economy expanded faster than the supply of precious metals its scarcity increased. The only way, then, that so much could be bought and sold was through the extensive use of credit. Probate records, diaries, and personal accounts all suggest that borrowing, lending, and purchase on credit were absolutely fundamental daily aspects of English society. Everyone, even the very poorest, was entangled in this web. More to the point, this was a time before credit became impersonal and bureaucratized, as it is today. Thus, the workings of the economy depended on people using an everyday calculus of reliability for those they traded with, a calculus based on a much wider sense of reputation than is familiar today. A person's credit depended on their economic standing and their moral worth. In fact, the two were largely indistinguishable.

The Economy of Obligation, which appeared in 1998, was not just economic history. Its methodology straddled traditional quantification, local history, the canonical diaries and autobiographies of the age, such as Samuel Pepys, William Stout and Richard Gough, and intellectual history. Its scope was so wide as to be of interest not just to economic and social historians, but cultural ones, legal ones, and students of political ideology too. It was, perhaps most of all, an attempt at a kind of economic history which also took account of culture. Simplified, the core argument is that, with such an expansion of credit, in an age when formal bureaucratic guarantees provided by the state were weak, economically active households had to find ways to trust one another. They did this through making a combination of economic and ethical judgements about each other. The early modern economy, says Muldrew, 'was a system of cultural, as well as material exchanges in which the central mediating factor was credit or trust' (p. 4). This was the culture of credit, in which the word 'credit' had a rather different meaning to today: it was moral and social as much as economic.

There are points in which the book is radical, even iconoclastic. Its picture of the scale of credit is perhaps its most startling finding. Part one of the book tries to calculate the level of market activity and credit 
transaction in England from the early 16th to the early 18th centuries. As with Muldrew's later work on food consumption and spinning, there are some heroically ambitious calculations. Nonetheless, despite the scale of the assumptions, they seem plausible and are - indeed - the best we have. What emerges is a complex, busy economy in which the availability of hard cash was scarcely adequate to account for even a tiny minority of transactions. If historians had long thought of England developing a market economy in the early modern period, then here it was - calculated in technicolour. In fact, Muldrew gives us a national consumption figure of $£ 146,000,000$ at the end of the 17 th century, more than three times the estimate for income produced by Gregory King. The book also argues - against the famous price data of Phelps-Brown and Hopkins (and now against the price data of other scholars such as Gregory Clark) - that living standards were actually improving during the period of population growth. Inventories show growing wealth, and the evidence for increased consumption is considerable, not least - for example - the 400,000 almanacs printed every year by the $1660 \mathrm{~s}$.

Perhaps it is fair to say that such an argument - which drew comment at the time - is rather less controversial now than it was then: work by Alex Shepard has shown, for example, the spectacular rise in the wealth of the yeomanry during the population growth. Indeed, it was not exactly new in 1998 either, anticipated as it was by the arguments made by D. M. Palliser in an important 1982 article. Students of poverty, though, might question some aspects of this. Muldrew suggests that the rise of poverty in this period was a rise in relative poverty. But this cannot be wholly true: sheer logic dictates that rising food prices and falling or stagnant wages will have curtailed the incomes of the labouring poor. The waves of vagrancy, the famines of the 1590 s and 1620 s, the constant government tinkering with the poor laws, cannot be explained away in terms of a growing income gap. Surely, absolute poverty was real and growing. What we are looking at, properly, is a society which was both getting wealthier and getting progressively more unequal, with more absolute poverty, at least until real wages started to rise again in the later 17th century. Nonetheless, at least one of Muldrew's calculations (towards the end of the book) does demand a major reconsideration of the way we think about poverty in the period. It is that more money - far more money, in fact - was redistributed through the forgiveness of debts than through formal poor relief or traditional charity. This was a startling finding, and surely a correct one, and it shows - perhaps - how small the amount spent on formal poor relief really was, and how much scope for growth in spending there was (incidentally, the book may show that the biggest brake on the growth of poor relief was not a lack of available wealth, but a lack of available coin).

Medievalists might also have some cause to grumble, if they see their own period as one of considerable economic maturity. With some due deference to these views, Muldrew essentially portrays the 16th century as the key turning point. It was then that the market economy really started to take off. But this, for me, runs into some difficulty. Why should 16th-century growth have spurred this on, but not growth in the 13th century? Indeed, given the (greater) scarcity of coin back then, should we not be looking for a 'culture of credit' in the reigns of Henry III and Edward I? One of the key pieces of evidence is the growth of litigation; but this was a wider phenomenon. Is perhaps part of what is happening an increase in the availability of litigation, and an increase in the survival of court records, meaning that we can see more credit transactions? If we had significantly more evidence from manorial and hundred courts in the 14th and 15th centuries, might these not push the establishment of an 'economy of obligation' back yet further in time?

Part two looks at the culture this world of credit created. This is an attempt, an important one, to write economic history with the culture put back in it. Ultimately, it asks how and why early moderns came to trust (or not to trust) one another. To do so, they made complicated judgements about reliability with which they measured their neighbours and potential debtors. Unlike today, this calculus had a strong moral and social element, although given the moral gloss added to 'thrift' (which was, of course, also an economic calculation) we should be circumspect about pigeonholing. Households that were disorderly and dishonest were less likely to be favourably looked upon. In one of its more Whiggish moments, the book suggests that this caused 'society' to be redefined. It no longer represented the medieval community united in Christian love, but became a complex collection of interpersonal relationships and obligations. In a sense, this ties in to the idea of a decline in neighbourliness: the economic culture identified by Muldrew was one which 
encouraged neighbours to judge one another's credit and thrift. Elements, then, of the puritan 'reformation of manners' can perhaps be identified as part of Muldrew's culture of credit. Alehouses were not just a scourge because they encouraged godlessness and the swearing of profane oaths, but because they were a honeytrap for the unthrifty. Every penny spent on ale, it could be argued, was a penny not spent repaying debts. Increasingly, indeed, creditworthy households were those on whom God had blessed worldly wealth, although it paid not to flash the cash too ostentatiously. The truly creditworthy were those who acted thriftily, shunning covetousness, though hopefully also showing just the right amount of generous liberality. It must have been a difficult balance to hold.

Part three, finally, explores two of the consequences of this credit economy. Firstly, it describes the growth in litigation. To Muldrew, litigiousness broadly followed the growth in the use of credit. As the market economy took off, so did the credit economy, and thus so did the use of law courts. The average late-Tudor household, Muldrew calculates, was engaged in around one lawsuit every year. In fact, Muldrew estimates (p. 236) that some 1,102,367 cases were launched a year in the late 16th century, the majority relating to credit transactions. It is an astonishing rate of litigiousness. Of course, this great wave of litigation - which was profoundly unsettling to many at the time - is well established, and here Muldrew's work complements well the research of the late Christopher Brooks into the social history of the early modern legal system. Muldrew's book, to my eyes, makes two especially crucial contributions to this. Firstly, it emphasizes how important disputes over credit were to the growth in litigation. Secondly, it shows how crucial the borough courts were, for they did not just handle disputes relating to the urban population, but were accessible to buyers and sellers in their hinterlands too. This meant that, for many, these neglected institutions were one of the most immediate points of contact with the 'state'.

This book, indeed, has some very interesting implications for the study of state formation, a topic which has become of particular interest to social historians in the years since 1998, with especially important contributions by Steve Hindle and Michael Braddick. The picture Muldrew gives us of a complex web of debt litigation in a multiverse of local law courts suggests that 'the state' was a much more intrusive element in peoples' lives than has sometimes been allowed. Moreover, it was becoming more so. Historians, myself included, tend to emphasize Parliament's 'stacks of statutes', the growth of a functioning militia, and the gradual emergence of the 'fiscal-military state'. But anyone who has used the voluminous records of the central law courts will also be aware that 'the state' was increasingly manifest through the legal system. Muldrew's book shows that the most immediate aspect of this may well have been debt litigation in the local courts, something perhaps not sufficiently acknowledged. The culture of credit created huge demands for dispute resolution, and the English state - through its legal system - charged into the breach. At the same time, peoples' attempts to thwart creditors who were working through law courts, such as by resisting or evading arrest, can be considered one of the trickier problems of the early modern state, lacking - as it did much of a police force.

The final chapter looks at downward social mobility. Historians have often looked for rising classes, and theorists have suggested a particular 'work ethic' might have encouraged some households to strive for upward mobility. But in fact, the mobility most people seem to have worried about was down the social scale. They worried that they would fall on misfortune and hard times. This was a point made in an influential 1995 article by Michael Mascuch, and Muldrew finds plenty of evidence to support this here. Moral judgements might be attached to the mutability of wealth: too much luxury and not enough thrift were often seen as to be blamed. 'Men', said Ralph Josselin, 'tumble up and downe in the world'. In fact, according to Muldrew's calculations, around 10 per cent of the population of Kings Lynn were 'at risk' of downward mobility each decade. Wealth was transient and misfortune was everywhere.

The Economy of Obligation is a brilliant and thought-provoking book. It is one which should profoundly influence the way we feel about early modern England and its economy. It shows, as Muldrew points out, a sophisticated market economy organized on very different cultural principles to our own. It is a dense book, which makes considerable demands on its readers, but it is worth the effort. In fact, for the early modern social and economic historian, it is obligatory. 
EH.Net

https://eh.net/book_reviews/the-economy-of-obligation-the-culture-of-credit-and-social-relations-in-earlymodern-england/ [2]

Times Higher Education

https://www.timeshighereducation.com/books/rules-that-shape-trust/158521.article [3]

Source URL:https://reviews.history.ac.uk/review/2043

\section{Links}

[1] https://reviews.history.ac.uk/item/165263 [2] https://eh.net/book_reviews/the-economy-of-obligation-theculture-of-credit-and-social-relations-in-early-modern-england/

[3] https://www.timeshighereducation.com/books/rules-that-shape-trust/158521.article 